sites have yielded charred and broken bones. Mr. Oliver sums up the reasons for the disappearance of what was once a considerable population, embracing many species of these specialized birds, in these words: "Man has been a great exterminator of species in all parts of the world; and so it seems with great probability that in New Zealand man contributed most to the disappearance of the moa. ... We know by numerous finds that man killed the moa for food and collected its eggs for the same purpose and for making utensils for water. . . The fact that the moa disappeared when man arrived points very strongly to these events being related, so whatever the causes for the decrease of the moa population during the Pleistocene period its final extingtion was due to man."

\section{Populdtion Distribution in England and Wales}

THe Registrar General for England and Wales has recently issued $\boldsymbol{a}$. goklet entitled "Estimates of the Sex and Age Digthibution of the Civilian Population in Regions Ad Administrative Areas of England and Weses 31st December, 1947" (London: H.M. Station fy Office, 2s. 6d.). This publication fills a gal which has been felt by all those who have had to work on local populations. Great changes have taken place in the distribution of the population and its age-composition since the last national census in 1931; the National Register of 1939 is also out of date and was taken at a time when evacuation and call-up distorted the picture. The present estimates are based on the maintenance files of local national registration offices, and the figures have been adjusted in the General Register Office. The civilian population only is covered; conscripts away on national service are therefore excluded, as are members of the mercantile marine. The omission of conscripts, who are away only for relatively short periods, is unfortunate, and it would have been desirable if an estimate of their numbers in different regions and localities could have been given. Figures are available for all local government areas down to district-level, and for the geographical regions of the General Register Office, as well as for the standard regions generally adopted for regional organisation by government departments. There are twelve age-groups for males and fourteen for females. It is to be hoped that a similar publication for Scotland will be issued, so that the whole of Great Britain will be covered. It is satisfactory to see that the much decried system of national registration can yield this valuable statistical byproduct.

\section{International Colloquium on Rheology in Biology}

AN interyational colloquium on biological topics that invgle problems in rheology has been arranged to tak place in Scandinavia during July 1950. It will last for approximately four days, during the interval between the Intermational Congress of Botany (Stockholm, July) and the Intermational Congress of Physiology (Copenhagen, August). The colloquium will include papers and addresses by workers in such fields as the circulation of blood, the mechanical properties of muscle, the movements of sap in plants and the rheological behaviour of protoplasm. It has been arranged under the auspices of the Joint Committee on Rheology of the International Cuuncil of Scientific Unions, by an organising sub-committee consisting of Prof. H. Eyring (Utah), Prof. A. Frey-Wyssling (Zurich), Prof. G. van Iterson (Delft) and Dr. P. Eggleton (Edinburgh). Further details can be obtained from Dr. P. Eggleton, Department of Physiology, University, Edinburgh.

\section{Course on Forestry in Scotland}

A coURse ón forestry in Scotland will be held during September 11-23, 1950, under the auspices of the British Council and arranged by the Forestry Depantment of the University of Aberdeen, in conjunction with the Forestry Commission. This course is intended for staffs of State forest services and of academic and research institutions in Commonwealth and foreign countries; the number of participants will be limited to twenty, and they must be proficient in English. Topics on the course will include the research which is being conducted at the University of Aberdeen on Scots pine (Pinus silvestris) and the so-called Scottish race of European larch (Larix decidua). The re-afforestation work of the Forestry Commission and the working of the Government scheme for the dedication of British woodlands will also be considered. Altogether four days will be spent in the University of Aberdeen and nine days on a tour through north and central Scotland. The estimated total cost, including return fare from London, will be $£ 28$ per person. Accommodation will be reserved in hotels. Further information, including method of application, can be obtained from the Area Officer, British Council, 22 Bridge Street, Aberdeen.

\section{Institute of Biglogy: First General Meeting}

THe first general meeting of the newly proposed Institute of Biology (Nature, 164, 776; 1949) will be held in the Great Hall, King's College, Strand, London, W.C.2, on January 5, at 6 p.m. The meeting is open to all biologists interested in the founding of this Institute.

The following have consented to serve on the first Council of the Institute: Dr. E. Hindle, F.R.S., Prof. T. A. Bennet-Clark, Prof. G. E. Blackman, Mr. L. J. F. Brimble, Prof. J. F. Danielli, Dr. D. G. Davey, Captain C. Diver, Dr. J. W. Evans, Prof. A. Graham, Prof. J. Gray, F.R.S., Prof. A. Haddow, Dr. J. Hammond, sen., F.R.S., Dr. C. Horton-Smith, Prof. W. H. Pearsall, F.R.S., Mr. N. W. Pirie, F.R.S., and Wing-Commander F. S. Russell, F.R.S.

\section{Paper for Periodicals}

Replynye to a question in the House of Commons on Decentiber 15, Mr. H. Wilson, president of the Board of Trade, stated that from March 1, 1950, existing magazines and periodicals would no longer bo limited for their home sales to a percentage of their pre-war consumption of paper, but would be allowed to use all the paper they could obtain. The restrictions on new publications would also be withdrawn.

\section{Announcements}

The Faraday Lecture for 1949-50 of the Institution of Electrical Engineers will be given by $\mathrm{Dr}$. R. A. Smith at the Central Hall, Westminster, London, S.W.1, on January 18, the subject being "Radar".

The Council of the Royal Society has made a grant of 21,000 towards the establishment of a Great Barrier Reef Marine Biological Station, probably on Heron Island. This grant is being made from a fund loft to the Society by the late E. T. Browne to aid marine expeditions and marine biological research. 